\title{
Aphicidal activities of Moroccan Bacillus thuringiensis strains against cotton aphid (Aphis gossypii)
}

\author{
Hassan Alahyane 1,*iD, Mohamed Ouknin 2(D), Abderrahim Alahyane ${ }^{3}$ (D), Houda Aboussaid ${ }^{1}$, Khalid \\ Oufdou $^{4}$ (D), Said El Messoussi ${ }^{1}$, Abdelaziz Mounir ${ }^{1(D)}$, Lhou Majidi ${ }^{2}$ (D)
}

1 Laboratory of Molecular and Ecophysiology Modelling, Faculty of Sciences Semlalia, University Cadi Ayyad, Marrakech, BP 2390, 40000 Morocco

2 Laboratory of Natural Substances Synthesis and Molecular Dynamics, Faculty of Sciences and Techniques, Moulay Ismail University, Errachidia, Morocco

3 Laboratory of Agro-Food, Biotechnologies and Valorization of Plant Bioresources, Cadi Ayyad University, Faculty of Sciences-Semlalia, Department of Biology, Marrakesh, Morocco

4 Laboratory of Microbial Biotechnologies, Agrosciences and Environment, Faculty of Sciences Semlalia, University Cadi Ayyad, Marrakech, BP 2390, 40000 Morocco

* Correspondence: alahyanerh@gmail.com (A.L.);

Scopus Author ID: 57208279544

Received: 12.06.2021; Revised: 25.07.2021; Accepted: 28.07.2021; Published: 8.08.2021

\begin{abstract}
The objective of this study was to evaluate the insecticidal effect of toxins from Moroccan Bacillus thuringiensis strains (Berliner) (Bt) on Aphis gossypii (Homoptera: Aphididae). Aphis gossypii is one of the most pests of Moroccan crops. Their management is based traditionally on using chemical products. Some of them are well known to be potentially toxic to the environment and human health. Therefore, alternative strategies for aphid management in crops have been developed in recent years, including a biological control using toxins of bacterial strains. In this study, the artificial diet bioassay was used to screen the aphicidal effect of $82 \mathrm{Bt}$ toxins against first instar nymphs and third instar nymphs of A. gossypii. Among the examined Bt strains, eleven showed a high insecticide activity against $A$. gossypii stages. In addition, the assessment of the lethal concentration $\left(\mathrm{LC}_{50}\right)$ of selected $\mathrm{Bt}$ revealed that the local BtA4, BtA1 and Bt21.6 exhibited higher insecticidal activity against first instar nymphs of $A$. gossypii $\left(\mathrm{LC}_{50}(\mathrm{BtA} 4)=0.15, \mathrm{LC}_{50}(\mathrm{BtA} 1)=0.23\right.$ and $\left.\mathrm{LC}_{50}(\mathrm{Bt} 21.6)=0.25 \mathrm{mg} / \mathrm{ml}\right)$ and the selected strains BtB6, BtA10 and Bt21.6 exhibited the relatively best activity third instar nymphs of $A$. gossypii $\left(\mathrm{LC}_{50}(\mathrm{BtB} 6)=0.48, \mathrm{LC}_{50}(\mathrm{BtA} 10)=0.79\right.$ and $\left.\mathrm{LC}_{50}(\mathrm{Bt} 21.6)=1.14 \mathrm{mg} / \mathrm{ml}\right)$ of A. gossypii. Therefore, the results of this study indicate that the selected $B$. thuringiensis strains have great potential to be used in the integrated A. gossypii management.
\end{abstract}

Keywords: Bacillus thuringiensis; Aphis gossypii; artificial diet bioassay; biotoxicity; $\mathrm{LC}_{50}$.

(C) 2021 by the authors. This article is an open-access article distributed under the terms and conditions of the Creative Commons Attribution (CC BY) license (https://creativecommons.org/licenses/by/4.0/).

\section{Introduction}

Aphis gossypii is one of the serious pests worldwide, infesting more than 500 plant species belonging to different families such as Cucurbitaceae, Solanaceae, Brassicaceae, Asteraceae, Malvaceae, Rosaceae, Amaranthaceae, among others [1, 2]. In Morocco, agricultural producers have encountered severe aphid problems despite the continuous applications of pesticides [3]. Aphids have a serious economic effect because of their pervasive proliferation due to their biological characteristics, specific polymorphism, and other alternating kinds of reproduction.

Aphis gossypii feeds on leaves causing damage to chlorophyll. In addition, they produce honeydew which allows sooty molds to grow, resulting in a decrease in fruit quantity and 
quality. To control A. gossypii, synthetic pesticides have been used by farmers. But the overuse of these chemical products during the past several years has caused many problems such as environmental pollution, harmful to beneficial insects, accumulation of toxicity at different trophic levels, and the emergence of resistance to pesticides [4, 5]. Therefore, a need to develop alternative strategies such as entomopathogenic bacterial toxins: Bacillus thuringiensis (Bt) has become necessary.

Bacillus thuringiensis is an aerobic Gram-positive bacterium. During sporulation, $B t$ produces the proteinaceous parasporal crystals $[6,7]$. These crystals consist of two types of proteins named Crystal (cry) and cytolytic (cyt) proteins [8], which are known for their insecticidal proprieties [9]. Proteins Cry has shown a high specificity to target insects and has been considered safe toward non-target organisms, plants, and humans, and completely biodegradable [10-13]. Therefore, $B t$ is one of the most effective biopesticides for insect control and represents roughly $2 \%$ of the total insecticide sales [14].

Several studies have shown $B t$ to be highly toxic against insects and mites of different orders [15-20]. In previous studies carried out in our laboratories, the $B t$ strains isolated from five different areas that Argania spinosa tree grows in Morocco showed a high insecticidal effect on Ceratitis capitata stages [21-23] and against Eutetranychus orientalis adults [17]. Thus, during the last years, there has been an important improvement in the screening of $B t$ collections to get isolation useful for pest control [24, 25]. Many aphid species have been found to be most vulnerable to Bt; such as the pea aphid Acyrthosiphon pisum [26], the potato aphid, Macrosiphum euphorbiae [15], the grain aphid Sitobion avenae [27], the green-peach aphid, Myzus persicae [28, 29] and the cotton aphid Aphis gossypii [30].

To our knowledge, there is no available study about the insecticidal effect of Moroccan $B t$ strains, especially those isolated from the endemic Argan forest on A. gossypii. Hence, this study aims to assess the toxicity effects of $B t$ strains, isolated from Argan regions in Morocco against $A$. gossypii stages, using artificial diet bioassay under laboratory conditions.

\section{Materials and Methods}

\subsection{Rearing of A. gossypii.}

A colony of A. gossypii was obtained from the Insectarium of Agafay orchards, Marrakech, Morocco (N31 30'04.0", W8 14'54.4"). The insect colonies had been reared for several generations at Agafay Insectarium. This aphid species were continuously reared on Phaseolus vulgaris L. under controlled conditions at $23 \pm 2{ }^{\circ} \mathrm{C}, 60 \pm 5 \%$ R.H., and with a $16: 8$ h (L:D) photoperiod.

\subsection{Production of Bt toxins.}

A loopful of bacteria taken from a colony of 82 strains grown in medium CCY agar was used to inoculate a tube with $4.5 \mathrm{ml}$ of medium CCY liquid (pre-culture) and then placed at $28^{\circ} \mathrm{C}$ during $48 \mathrm{~h}$ with $200 \mathrm{rpm}$ of agitation to grow. To verify the formation of the toxins (over $90 \%$ sporulation is optimum), an aliquot was taken from the pre-culture and observed under phase-contrast microscopy (DM2500, Leica Microsystems, Germany). The pre-culture was heated at $70^{\circ} \mathrm{C}$ for 20 minutes to eliminate the vegetative cells. $40 \mathrm{ml}$ of the main culture was inoculated with 1/1,000 volumes of synchronized pre-culture and incubated as mentioned above. Then the whole culture was centrifuged for 10 minutes at $9,000 \times \mathrm{g}$. 
The supernatant was discarded, and the pellet was washed once with ice-cold $1 \mathrm{~mol} / \mathrm{l}$ $\mathrm{NaCl}$ and $10 \mathrm{Mmol} / \mathrm{l}$ EDTA solutions. Then the pellet was concentrated by lyophilization to express the $B t$ toxins in $\mathrm{mg}$ and stored at $-20{ }^{\circ} \mathrm{C}$ until bioassays. All steps have been done on ice to limit the proteolysis after centrifugation.

\subsection{Selection of active bacterial strains.}

In order to select the $B t$ strains with high toxicity effects against $A$. gossypii nymphs. We conducted preliminary dose setting experiments with first and third instar nymphs of A. gossypii using an artificial diet [29]. This diet contained $500 \mathrm{mM}$ sucrose (pH: 7.5-8), $150 \mathrm{mM}$ amino acids, minerals, and vitamins, and different dilutions of toxins. The $B t$ strains that showed a high percentage of mortality, over $75 \%$, were selected to be used in the experiment. Based on the preliminary trial, eleven $B t$ strains were selected between eighty tows (Table 1). Five concentrations ( 0 (control), $0.1,0.5,1,2$, and $3 \mathrm{mg} / \mathrm{ml}$ ) were chosen to be used in the experiment, and $150 \mu 1$ of each concentration was mixed with the artificial diet.

Table 1. Morphological characterization (phase-contrast microscopy), biochemical (SDS-PAGE), and genetic (SDS-PAGE and PCR) of the 11 Moroccan strains of the selected Bts.

\begin{tabular}{c|c|c|c}
$\mathbf{N}^{\circ}$ & Strains & Crystal form & Gene cry (PCR) \\
\hline 1 & Bt A1 & Spherical & cry7/8 \\
\hline 2 & Bt A4 & Irregular & cry7/8+cry9 \\
\hline 3 & Bt A10 & Spherical & cry4+cry7/8 \\
\hline 4 & Bt A14 & Spherical & Cry 11 \\
\hline 5 & Bt A-Mg Mg2.7 & Spherical \\
\hline 6 & Bt B6 & Spherical & cry7/8+cry9 \\
\hline 7 & Bt21.6 & Irregular & cry4+cry11+cyt1 \\
\hline 8 & Bt 9 & Irregular 4 \\
\hline 9 & Bt 32.2 & Crystal $>1$ & cry 4 \\
\hline 10 & Bt 26.4 & Spherical & cry 9 \\
\hline 11 & Bt 32.3 & Irregular &
\end{tabular}

\subsection{Bioassay.}

The feeding membrane assays were used to assess the toxicity of selective strains of $\mathrm{Bt}$ against first and third instar nymphs of A. gossypii. Different concentrations of toxins of each strain were mixed with the artificial. No toxins were added to the control. The diet was presented to aphids in stretched parafilm sachets containing $0.4 \mathrm{ml}$ of artificial diet. Plastic tubes opening at both ends (cylindrical plastic tubes with $5 \mathrm{~cm}$ diameter and $4 \mathrm{~cm}$ height) were used as a test chamber (Figure 1). The diet in the form of stretched parafilm sachet was deposited into the test chamber. The other end was covered with a muslin cloth with fine mesh. From this end, 20 first instar nymphs and the third instar nymphs of A. gossypii were introduced. The concentration of $B t$ toxins was 3,2, $1,0.5$ and $0.1 \mathrm{mg} / \mathrm{ml}$. Each concentration was replicated five times for each strain. The sterile distilled water was used as a negative control and the commercial Bt strain BT-M as a positive control. The bioassays were conducted under laboratory conditions at $23 \pm 2{ }^{\circ} \mathrm{C}, 60 \pm 5 \%$ R.H., and a 16: $8 \mathrm{~h}$ (L:D) photoperiod. Aphid stage mortality was recorded after 3 days of treatment. 


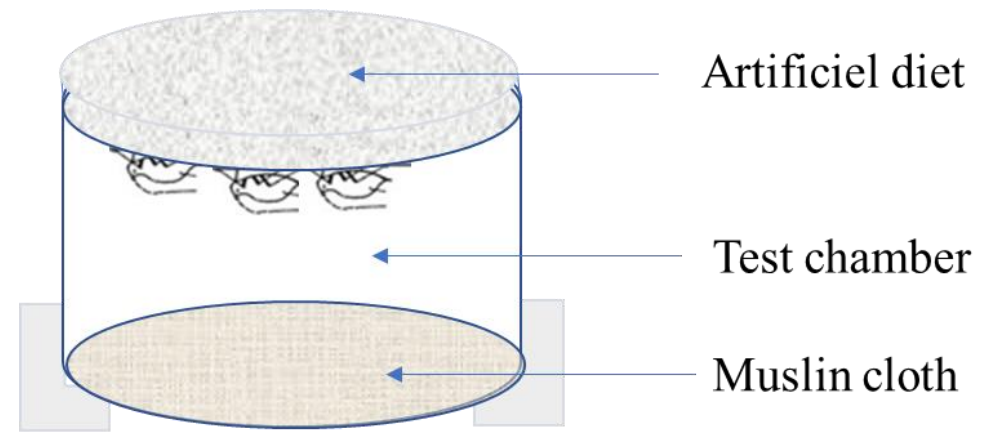

Figure 1. Test chamber: a plastic cylinder with $5 \mathrm{~cm}$ diameter and $4 \mathrm{~cm}$ height, with a mesh on the bottom and the top open. On this open side, the diet sachet was introduced.

\subsection{Statistical Analysis.}

The lethal concentrations' values ( $\mathrm{LC}_{50}$ and $\mathrm{LC}_{90}$ ) were calculated by using probit analysis SPSS 25.0 Statistical Software. The confidence interval of estimate LC values was $95 \%$, and when the LC values did not overlap, they were considered significantly different.

\section{Results}

\subsection{Insect bioassay.}

Among the $82 \mathrm{Bt}$ strains evaluated against first instar nymphs of A. gossypii through the selective bioassays, only fifteen strains showed insecticidal mortality greater than $75 \%$, corresponding to $13.41 \%$ of the strains (Table 2). Most of the strains (42.68\%) exhibited very low toxicity (0-25\% mortality) against $A$. gossypii nymphs, $29.28 \%$ of the strains had low toxicity (25.1-50\% mortality), and $14.63 \%$ of the strains were moderately toxic, causing mortality from 50.1 to $75 \%$ mortality (Table 2 ).

Table 2. Groups of $B t$ strains based on their toxicity against $A$. gossypii stages.

\begin{tabular}{c|c|c|c} 
Group & Toxicity against $\boldsymbol{A}$. gossypii in \% mortality & Number of strains & \% of strains \\
\hline I & $0-25$ & 35 & 42.68 \\
\hline II & $25.1-50$ & 24 & 29.28 \\
\hline III & $50.1-75$ & 8 & 14.63 \\
\hline IV & $75-100$ & 15 & 13.41
\end{tabular}

\subsection{Toxicity effect of Bt strains against first instar nymphs.}

The insecticidal activities of selected $B t$ strain against first instar nymphs of $A$. gossypii are presented in Table 3. The control did not show any nymph mortality. The nymphicidal activity varied with tested $B t$ strains. Among the selected strains BtA4, BtA1 and Bt21.6 exhibited the highest potency with $\mathrm{LC}_{50}$ values of $0.15,0.23$ and $0.25 \mathrm{mg} / \mathrm{ml}$ and $\mathrm{LC}_{90}$ values of $0.53,0.73$ and $0.89 \mathrm{mg} / \mathrm{ml}$, respectively. The lowest efficacy was observed for Bt26.4, BtA14, and BtB9 with $\mathrm{LC}_{50}$ values of $2.94,3.19$ and $3.94 \mathrm{mg} / \mathrm{ml}$ and $\mathrm{LC}_{90}$ values of $7.41,9.65$ and $10.90 \mathrm{mg} / \mathrm{ml}$. The five remaining $B t$ strains show intermediate nymphicidal activity. The $\mathrm{LC}_{50}$ values of these strains were statistically similar to that of the strain Bt-M that showed $\mathrm{LC}_{50}$ of $1.37 \mathrm{mg} / \mathrm{ml}$. 
Table 3. $\mathrm{LC}_{50}$ and $\mathrm{LC}_{90}$ values of the selected $B t$ strains against first instar nymphs of $A$. gossypii after 3 days of

\begin{tabular}{c|c|c|c|c}
\multicolumn{7}{|c}{ Strains } & LC $\mathbf{5 0}(\mathbf{9 5} \% \mathbf{C I})(\mathbf{m g} / \mathbf{m l})$ & $\mathbf{L C} \mathbf{9 0}(\mathbf{9 5 \%} \mathbf{C I})(\mathbf{m g} / \mathbf{m l})$ & Slope $\pm \mathbf{S E}$ & $\boldsymbol{\chi} \mathbf{2}(\mathbf{d f}=\mathbf{4})$ \\
\hline Bt A1 & $0.23(0.15-1.29)$ & $0.73(0.37-3.02)$ & $1.53 \pm 0.19$ & 3.65 \\
\hline Bt A4 & $0.15(0.11-0.93)$ & $0.53(0.29-2.63)$ & $2.72 \pm 0.14$ & 11.82 \\
\hline Bt A10 & $1.21(1.03-1.48)$ & $3.27(2.36-4.09)$ & $1.81 \pm 0.09$ & 8.01 \\
\hline Bt A14 & $3.19(3.00-4.38)$ & $9.65(6.48-13.02)$ & $2.13 \pm 0.61$ & 9.32 \\
\hline Bt A-Mg Mg2.7 & $2.21(1.89-3.76)$ & $6.28(4.60-9.73)$ & $3.47 \pm 0.32$ & 3.95 \\
\hline Bt B6 & $0.85(0.23-1.49)$ & $2.07(0.87-4.42)$ & $1.21 \pm 0.09$ & 21.55 \\
\hline Bt21.6 & $0.25(0.16-1.76)$ & $0.89(0.75-3.74)$ & $1.13 \pm 0.91$ & 4.25 \\
\hline Bt B9 & $3.94(2.02-5.07)$ & $10.90(4.83-13.03)$ & $2.03 \pm 0.25$ & 2.16 \\
\hline Bt32.2 & $1.39(1.16-1.76)$ & $3.88(3.12-6.59)$ & $1.39 \pm 0.26$ & 7.49 \\
\hline Bt26.4 & $2.94(1.52-7.17)$ & $7.41(4.47-18.58)$ & $2.56 \pm 1.92$ & 10.21 \\
\hline Bt 32.3 & $1.58(1.18-4.72)$ & $3.55(2.53-6.81)$ & $1.84 \pm 0.52$ & 6.15 \\
\hline Bt-M & $1.37(1.02-2.97)$ & $4.27(3.44-6.18)$ & $4.46 \pm 2.12$ & 13.07
\end{tabular}

\subsection{Toxicity effect of Bt strains against third instar nymphs.}

The data shown in Table 4 revealed that all tested $B t$ strains showed an interesting nymphicidal potency against the third instar nymphs of $A$. gossypii, whereas in the controls, any mortality did not observe. The strains Bt B6, Bt A10 and Bt21.6 showed the highest nymphicidal activity with LC 50 values of $0.16,0.31$ and $0.36 \mathrm{mg} / \mathrm{ml}$ and $\mathrm{LC}_{90}$ values of 0.48 , 0.79 and $1.14 \mathrm{mg} / \mathrm{ml}$. Intermediate $\mathrm{LC}_{50}$ values of $0.84,1.27$ and $1.34 \mathrm{mg} / \mathrm{ml}$ were recorded for Bt A4, Bt A1 and Bt32.2, respectively. The $\mathrm{LC}_{50}$ values of these strains were statistically similar to the strain Bt-M that showed $\mathrm{LC}_{50}$ of $0.95 \mathrm{mg} / \mathrm{ml}$. The five remaining $B t$ strains show the lowest nymphicidal potency.

Table 4. $\mathrm{LC}_{50}$ and $\mathrm{LC}_{90}$ values of the selected $B t$ strains against third instar nymphs of $A$. gossypii after 3 days of bioassay.

\begin{tabular}{c|c|c|c|c} 
Strains & LC $\left._{\mathbf{5 0}}(\mathbf{9 5 \%} \mathbf{C I}) \mathbf{( m g} / \mathbf{m l}\right)$ & $\left.\left.\mathbf{L C}_{\mathbf{9 0}} \mathbf{( 9 5 \%} \mathbf{C I}\right) \mathbf{( m g} / \mathbf{m l}\right)$ & Slope $\pm \mathbf{S E}$ & $\boldsymbol{\chi} \mathbf{2}(\mathbf{d f}=\mathbf{4})$ \\
\hline BtA1 & $1.27(1.02-1.41)$ & $3.48(2.21-4.42)$ & $2.37 \pm 0.17$ & 3.26 \\
\hline BtA4 & $0.84(0.29-1.11)$ & $2.78(0.99-4.21)$ & $3.42 \pm 1.92$ & 11.61 \\
\hline BtA10 & $0.31(0.19-1.12)$ & $0.79(0.32-3.15)$ & $1.32 \pm 0.45$ & 8.27 \\
\hline BtA14 & $3.23(3.16-5.34)$ & $9.58(9.08-12.55)$ & $2.63 \pm 1.01$ & 2.01 \\
\hline BtA-Mg Mg2.7 & $2.08(1.78-3.24)$ & $5.39(4.41-8.91)$ & $1.82 \pm 0.78$ & 2.19 \\
\hline BtB6 & $0.16(0.12-0.29)$ & $0.48(0.83-2.31)$ & $2.31 \pm 0.24$ & 17.82 \\
\hline Bt21.6 & 0.36 & 1.14 & $2.51 \pm 0.90$ & 3.19 \\
\hline BtB9 & $3.72(1.68-6.21)$ & $7.48(2.97-9.48)$ & $1.91 \pm 1.05$ & 9.81 \\
\hline Bt32.2 & $1.34(0.99-2.10)$ & $4.26(2.41-7.18)$ & $1.65 \pm 0.61$ & 16.05 \\
\hline Bt26.4 & 2.32 & 5.67 & $0.95 \pm 0.05$ & 5.14 \\
\hline Bt32.3 & $1.80(1.11-3.05)$ & $5.42(2.98-11.24)$ & $1.43 \pm 0.11$ & 19.13 \\
\hline Bt-M & $0.95(0.64-2.03)$ & $2.52(1.89-4.21)$ & $2.01 \pm 0.59$ & 9.22
\end{tabular}

\section{Discussion}

Actually, many control methods, including chemical insecticides, biological control, $B t$ crops, and cultural practices, have been used in integrated aphid management to achieve more effective crop protection [31-34]. The environmental, social, and economic benefits offered by the $B t$ bioinsecticides and insect-resistant $B t$ plants have driven increasing adoption of these management approaches for managing insect pests belonging to divers' orders of [35-38]. However, pest populations can develop resistance to several types of $B t$ pesticide proteins, whether under open field or controlled conditions, reducing bioinsecticides and transgenic plants [39]. This scenario encourages the research for novel $B t$ strains and genes that can be used in integrated pest management strategies.

In the current study, the aphicides activities of $B t$ strains were evaluated to discover a promising strain to be used in developing biopesticides against A. gossypii. We found that 
$18.29 \%$ of studied strains were highly toxic against 1st-instar and 3rd instar nymphs of $A$. gossypii. In addition, among the selected strains, BtA4, BtA1, and $\mathrm{Bt} 21.6$ displayed the highest toxicity against the 1st-instar, while the selected strains BtB6, BtA10, and Bt21.6 showed the high nymphicidal potency on 3rd instar of $A$. gossypii as they had displayed the lowest LC50,90 values. Some studies have shown that the proportion of strains toxic to different orders of insect stages is often low, as shown in our study $[22,40]$. Our result showed that the toxicity of selected strains varied considerably towards the A. gossypii stages. The strain $\mathrm{Bt} 21.6$ caused a high level of mortality to both stages of aphid, whereas strain Bt B9 had low toxicity on aphid stages. Furthermore, the strain BtA4 was effective on 1st-instar, while the strain BtA10 had high toxicity towards the 3rd instar of A. gossypii. Our study showed that some Bt strains had a wide range of activity against both stages of $A$. gossypii, other strains were more specific, showing that the screening of the insecticidal effect of the Bt strains against insect pests under controlled conditions is a crucial step to discover the strains that had a great efficiency and to evaluate their feasibility to be used as biopesticides.

The difference in susceptibility of $A$. gossypii stages on the selected Bt strains in the current study may be explained by the genes that coding for aphicidal activity against the two stages of the aphid could be different [41,22]. The chemical composition of the gut of the two stages of aphid could be affecting the solubilization and proteolytic processing of Bt proteins, therefore the activation or inactivation of the protoxin $[42,43]$. In addition, other factors can influence the effectiveness of $B t$ strain, such as the antagonistic or synergistic interactions between $B t$ proteins (Cry and Vip) [44].

Many research on the efficacy of $B t$ that have indicated an insecticidal activity against aphids and other Homoptera insects. In fact, Torres-Quintero et al. [45] and Palma et al. [28] confirm that Bt strains tested in the bioassays are responsible for the mortality of Myzus persicae (Sulzer) (Hemiptera: Aphididae) after being fed with different toxins of $B$. thuringiensis strains. However, it is interesting to point out that other studies have shown contrasting results. Macintosh et al. [46] showed that the green-peach aphid was insensitive to many $B t$ toxins. Furthermore, Oatman [47] reported that $B t$ toxins were not inefficient in controlling Apple Aphid. The difference observed between the studies mentioned above and our results could be related to two eventual factors: the types of the Cry proteins produced by $B t$ strains or the possibility of the presence of other genes not identified. Further studies are needed to discover all cry genes that may contribute to these studied strains' toxicity.

$B t$ strains with diverse genes might synthesize many Cry and Vip proteins, which may have increased toxicity and target a wider range of pests [48]. In fact, the presence of many cry genes allowed the variation of active modes of synthesized Cry proteins that may decrease the risk of development of resistance in the target pest populations $[49,50]$. In concordance with this, our results showed that the five studied BtB6, BtA10, BtA4, BtA1, and Bt21.6 were the most toxic to studied aphid stages and these $B t$ strains showed a high diversity of cry genes. Nonetheless, our results suggest that the selected strains may be a potential source of genes for the development of insect-resistant transgenic crops.

\section{Conclusions}

The current work identified $B t$ strains that have shown a great potential to be used in the formulation of biopesticides for integrated aphid management. In addition, the selected $B t$ strains may contain the genes for applications in the production of transgenic plants. Further 
research is needed in the open field and greenhouse to evaluate the effectiveness of selected strains to control A. gossypii.

\section{Funding}

This research received no external funding.

\section{Acknowledgments}

This research has no acknowledgment.

\section{Conflicts of Interest}

The authors declare that they have no competing interests.

\section{References}

1. Singh, G.; Singh, N.P.; Singh, R. Food plants of a major agricultural pest Aphis gossypii Glover (Homoptera: Aphididae) from India: An updated checklist. International Journal of Life Sciences Biotechnology and Pharma Research 2014, 3, 1.

2. Centre for Agriculture and Bioscience International (CABI). Invasive Species Compendium, Database for Aphis gossypii (cotton aphid) 2020, Available: https://www.cabi.org/isc/datasheet/6204\#tosummaryOfInvasiveness.

3. Raada, S.; Mazouz, H.; Boulif, M. Phytosanitary practices of apple growers in the Ifrane province of the Middle Atlas of Morocco and perspectives of improvement. Revue Marocaine de Protection des Plantes 2019.

4. Win, P.M.; Matsumura, E.; Fukuda, K. Effects of pesticides on the diversity of Endophytic Fungi in Tea plants. Microb. Ecol. 2021, https://doi.org/10.1007/s00248-020-01675-7.

5. Siviter, H.; Muth, F. Do novel insecticides pose a threat to beneficial insects? Proceedings of the Royal Society B: Biological Sciences 2020, 287, 20201265, https://doi.org/10.1098/rspb.2020.1265.

6. Blanc, M.; Kaelin, P.; Gadani, F. Bacillus thuringiensis (Bt) for the Control of Insect Pests in Stored Tobacco: A Review. Beiträge zur Tabakforschung International/Contributions to Tobacco Research 2014, 20, 15-22, https://doi.org/10.2478/cttr-2013-0727.

7. Aboul-Soud, M.A.M.; Al-Amri, M.Z.; Kumar, A.; Al-Sheikh, Y.A.; Ashour, A.E.; El-Kersh, T.A. Specific Cytotoxic effects of parasporal Crystal proteins isolated from native Saudi Arabian Bacillus thuringiensis Strains against Cervical Cancer Cells. Molecules 2019, 24, https://doi.org/10.3390/molecules24030506.

8. Crickmore, N.; Berry, C.; Panneerselvam, S.; Mishra, R.; Connor, T.R.; Bonning, B.C. A structure-based nomenclature for Bacillus thuringiensis and other bacteria-derived pesticidal proteins. J. Invertebr. Pathol. 2020, https://doi.org/10.1016/j.jip.2020.107438.

9. hakroun, M.; Banyuls, N.; Bel, Y.; Escriche, B.; Ferré, J. Bacterial vegetative insecticidal proteins (Vip) from Entomopathogenic Bacteria. Microbiol. Mol. Biol. Rev. 2016, 80, 329-350, https://doi.org/10.1128/MMBR.00060-15.

10. Bravo, A.; Gill, S.S.; Soberón, M. Mode of action of Bacillus thuringiensis Cry and Cyt toxins and their potential for insect control. Toxicon 2007, 49, 423-435, https://doi.org/10.1016/j.toxicon.2006.11.022.

11. Roh, J.Y.; Choi, J.Y.; Li, M.S.; Jin, B.R.; Je, Y.H. Bacillus thuringiensis as a specific, safe, and effective tool for insect pest control. J. Microbiol. Biotechnol. 2007, 17, 547-559.

12. Koch, M.S.; Ward, J.M.; Levine, S.L.; Baum, J.A.; Vicini, J.L.; Hammond, B.G. The food and environmental safety of Bt crops. Frontiers in plant science 2015, 6, 283, https://doi.org/10.3389/fpls.2015.00283.

13. Jurat-Fuentes, J.L.; Crickmore, N. Specificity determinants for Cry insecticidal proteins: Insights from their mode of action. J. Invertebr. Pathol. 2017, 142, 5-10, https://doi.org/10.1016/j.jip.2016.07.018.

14. Adang, M.J.; Crickmore, N.; Jurat-Fuentes, J.L. Chapter Two - Diversity of Bacillus thuringiensis Crystal toxins and mechanism of action. In Adv. Insect Physiol., Dhadialla, T.S., Gill, S.S., Eds. Academic Press: 2014; 47, 39-87, https://doi.org/10.1016/B978-0-12-800197-4.00002-6.

15. Walters, F.S.; English, L.H. Toxicity of Bacillus thuringiensis $\delta$ - endotoxins toward the potato aphid in an artificial diet bioassay. Entomol. Exp. Appl. 1995, 77, 211-216, https://doi.org/10.1111/j.15707458.1995.tb02003.x. 
16. Griffitts, J.S.; Aroian, R.V. Many roads to resistance: how invertebrates adapt to Bt toxins. Bioessays 2005 , 27, 614-624, https://doi.org/10.1002/bies.20239.

17. Alahyane, H.; El Alaoui, A.; Abousaid, H.; Aimrane, A.; Atibi, Y.; Oufdou, K.; El Messoussi, S. Biological activity of some native Bacillus thuringiensis Berliner strains against Eutetranychus orientalis Klein (Acari: Tetranychidae). Appl. Ecol. Environ. Res. 2019, 17, 1967-1977, http://dx.doi.org/10.15666/aeer/1702_19671977 .

18. Valtierra-de-Luis, D.; Villanueva, M.; Berry, C.; Caballero, P. Potential for Bacillus thuringiensis and Other Bacterial Toxins as Biological Control Agents to Combat Dipteran Pests of Medical and Agronomic Importance. Toxins (Basel) 2020, 12, https://doi.org/10.3390/toxins12120773.

19. Hang, P.L.B.; Linh, N.N.; Ha, N.H.; Dong, N.V.; Hien, L.T.T. Genome sequence of a Vietnamese Bacillus thuringiensis strain TH19 reveals two potential insecticidal crystal proteins against Etiella zinckenella larvae. Biol. Control 2021, 152, 104473, https://doi.org/10.1016/j.biocontrol.2020.104473.

20. Paul, S.; Das, S. Natural insecticidal proteins, the promising bio-control compounds for future crop protection. The Nucleus 2021, 64, 7-20, https://doi.org/10.1007/s13237-020-00316-1.

21. Aboussaid, H.; El Messoussi, S.; Oufdou, K. Activité insecticide d'une souche marocaine de Bacillus thuringiensis sur la mouche méditerranéenne: Ceratitis capitata (Wied.)(Diptera: Tephritidae). Afrique Science: Revue Internationale des Sciences et Technologie 2009, 5, 160-172, https://doi.org/10.4314/afsci.v5i1.61719.

22. Aboussaid, H.; El-Aouame, L.; El-Messoussi, S.; Oufdou, K. Biological activity of Bacillus thuringiensis (Berliner) strains on larvae and adults of Ceratitis capitata (Wiedemann)(Diptera: Tephritidae). J. Environ. Prot. (Irvine, Calif.) 2010, 1, 337, https://doi.org/10.4236/jep.2010.14040.

23. Aboussaid, H.; Vidal-Quist, J.C.; Oufdou, K.; El Messoussi, S.; Castañera, P.; González-Cabrera, J. Occurrence, characterization and insecticidal activity of Bacillus thuringiensis strains isolated from argan fields in Morocco. Environ. Technol. 2011, 32, 1383-1391, https://doi.org/10.1080/09593330.2010.536789.

24. Kranthi, K.R.; Stone, G.D. Long-term impacts of Bt cotton in India. Nature Plants 2020, 6, 188-196, https://doi.org/10.1038/s41477-020-0615-5.

25. dos Santos, C.A.M.; do Nascimento, J.; Gonçalves, K.C.; Smaniotto, G.; de Freitas Zechin, L.; da Costa Ferreira, M.; Polanczyk, R.A. Compatibility of Bt biopesticides and adjuvants for Spodoptera frugiperda control. Sci. Rep. 2021, 11, 5271, https://doi.org/10.1038/s41598-021-84871-w .

26. Li, H.; Chougule, N.P.; Bonning, B.C. Interaction of the Bacillus thuringiensis delta endotoxins Cry1Ac and Cry3Aa with the gut of the pea aphid, Acyrthosiphon pisum (Harris). J. Invertebr. Pathol. 2011, 107, 69-78, https://doi.org/10.1016/j.jip.2011.02.001.

27. Ramirez-Romero, R.; Desneux, N.; Chaufaux, J.; Kaiser, L. Bt-maize effects on biological parameters of the non-target aphid Sitobion avenae (Homoptera: Aphididae) and Cry1Ab toxin detection. Pestic. Biochem. Physiol. 2008, 91, 110-115, https://doi.org/10.1016/j.pestbp.2008.01.010.

28. Palma, L.; Muñoz, D.; Berry, C.; Murillo, J.; De Escudero, I.R.; Caballero, P. Molecular and insecticidal characterization of a novel Cry-Related protein from Bacillus thuringiensis toxic against Myzus persicae. Toxins (Basel) 2014, 6, https://doi.org/10.3390/toxins6113144.

29. López-Isasmendi, G.; Alvarez, A.E.; Petroselli, G.; Erra-Balsells, R.; Audisio, M.C. Aphicidal activity of Bacillus amyloliquefaciens strains in the peach-potato aphid (Myzus persicae). Microbiol. Res. 2019, 226, 41-47, https://doi.org/10.1016/j.micres.2019.05.006.

30. Melatti, V.M.; Praça, L.B.; Martins, E.S.; Sujii, E.; Berry, C.; Monnerat, R.G. Selection of Bacillus thuringiensis strains toxic against cotton aphid, Aphis gossypii Glover (Hemiptera: Aphididae). BioAssay. 2010, 5, 1-4, https://doi.org/10.14295/BA.v5.0.70.

31. Song, F.; Swinton, S.M. Returns to Integrated Pest Management Research and Outreach for Soybean Aphid. J. Econ. Entomol. 2009, 102, 2116-2125, https://doi.org/10.1603/029.102.0615.

32. Dardouri, T.; Gomez, L.; Ameline, A.; Costagliola, G.; Schoeny, A.; Gautier, H. Non-host volatiles disturb the feeding behavior and reduce the fecundity of the green peach aphid, Myzus persicae. Pest Manage. Sci. 2021, 77, 1705-1713, https://doi.org/10.1002/ps.6190.

33. Dean, A.N.; Niemi, J.B.; Tyndall, J.C.; Hodgson, E.W.; O'Neal, M.E. Developing a decision-making framework for insect pest management: a case study using Aphis glycines (Hemiptera: Aphididae). Pest Manage. Sci. 2021, 77, 886-894, https://doi.org/10.1002/ps.6093.

34. Hoidal, N.; Koch, R.L. Perception and use of economic thresholds among farmers and agricultural professionals: A case study on Soybean aphid in Minnesota. Journal of Integrated Pest Management 2021, 12, https://doi.org/10.1093/jipm/pmab003.

35. Dively, G.P.; Venugopal, P.D.; Bean, D.; Whalen, J.; Holmstrom, K.; Kuhar, T.P.; Doughty, H.B.; Patton, T.; Cissel, W.; Hutchison, W.D. Regional pest suppression associated with widespread Bt maize adoption benefits vegetable growers. Proceedings of the National Academy of Sciences 2018, 115, 3320, https://doi.org/10.1073/pnas.1720692115. 
36. Brookes, G. Twenty-one years of using insect resistant (GM) maize in Spain and Portugal: farm-level economic and environmental contributions. GM Crops \& Food 2019, 10, 90-101, https://doi.org/10.1080/21645698.2019.1614393.

37. Romeis, J.; Naranjo, S.E.; Meissle, M.; Shelton, A.M. Genetically engineered crops help support conservation biological control. Biol. Control 2019, 130, 136-154, https://doi.org/10.1016/j.biocontrol.2018.10.001.

38. He, L.-m.; Zhao, S.-y.; Gao, X.-w.; Wu, K.-m. Ovipositional responses of Spodoptera frugiperda on host plants provide a basis for using Bt-transgenic maize as trap crop in China. Journal of Integrative Agriculture 2021, 20, 804-814, https://doi.org/10.1016/S2095-3119(20)63334-2.

39. Jurat-Fuentes, J.L.; Heckel, D.G.; Ferré, J. Mechanisms of Resistance to Insecticidal proteins from Bacillus thuringiensis. Annu. Rev. Entomol. 2021, 66, 121-140, https://doi.org/10.1146/annurev-ento-052620-073348.

40. Lone, S.A.; Malik, A.; Padaria, J.C. Selection and characterization of Bacillus thuringiensis strains from northwestern Himalayas toxic against Helicoverpa armigera. MicrobiologyOpen 2017, 6, e00484, https://doi.org/10.1002/mbo3.484.

41. Robacker, D.C.; Martinez, A.J.; Garcia, J.A.; Diaz, M.; Romero, C. Toxicity of Bacillus thuringiensis to Mexican Fruit Fly (Diptera: Tephritidae). J. Econ. Entomol. 1996, 89, 104-110, https://doi.org/10.1093/jee/89.1.104.

42. Alberola, T.M.; Aptosoglou, S.; Arsenakis, M.; Bel, Y.; Delrio, G.; Ellar, D.J.; Ferré, J.; Granero, F.; Guttmann, D.M.; Koliais, S.; Martínez-Sebastián, M.J.; Prota, R.; Rubino, S.; Satta, A.; Scarpellini, G.; Sivropoulou, A.; Vasara, E. Insecticidal activity of strains of Bacillus thuringiensis on larvae and adults of Bactrocera oleae Gmelin (Dipt. Tephritidae). J. Invertebr. Pathol. 1999, 74, 127-136, https://doi.org/10.1006/jipa.1999.4871.

43. Talaei-Hassanloui, R.; Bakhshaei, R.; Hosseininaveh, V.; Khorramnezhad, A. Effect of midgut proteolytic activity on susceptibility of lepidopteran larvae to Bacillus thuringiensis subsp. kurstaki. Front. Physiol. 2014, 4, 406, https://doi.org/10.3389/fphys.2013.00406.

44. Lemes, A.R.N.; Davolos, C.C.; Legori, P.C.B.C.; Fernandes, O.A.; Ferré, J.; Lemos, M.V.F.; Desiderio, J.A. Synergism and antagonism between Bacillus thuringiensis Vip3A and Cry1 proteins in Heliothis virescens, Diatraea saccharalis and Spodoptera frugiperda. PLoS One 2014, 9, e107196, https://doi.org/10.1371/journal.pone.0107196.

45. Torres-Quintero, M.C.; Arenas-Sosa, I.; Hernández-Velázquez, V.M.; Suárez-Rodríguez, R.; Peña-Chora, G. Characterization of Bacillus thuringiensis (Bacillaceae) strains pathogenic to Myzus persicae (Hemiptera: Aphididae). Fla. Entomol. 2016. 99, 639-643. https://doi.org/10.1653/024.099.0409.

46. MacIntosh, S.C.; Stone, T.B.; Sims, S.R.; Hunst, P.L.; Greenplate, J.T.; Marrone, P.G.; Perlak, F.J.; Fischhoff, D.A.; Fuchs, R.L. Specificity and efficacy of purified Bacillus thuringiensis proteins against agronomically important insects. J. Invertebr. Pathol. 1990, 56, 258-266, https://doi.org/10.1016/00222011(90)90109-j.

47. Oatman, E.R. The Effect of Bacillus thuringiensis Berliner on some lepidopterous larval pests, Apple aphid and predators, and on phytophagous and predaceous mites on young Apple trees1. J. Econ. Entomol. 1965, 58, 1144-1147, https://doi.org/10.1093/jee/58.6.1144.

48. Domínguez-Arrizabalaga, M.; Villanueva, M.; Escriche, B.; Ancín-Azpilicueta, C.; Caballero, P. Insecticidal activity of Bacillus thuringiensis proteins against Coleopteran pests. Toxins (Basel) 2020, 12, https://doi.org/10.3390/toxins12070430.

49. Qi, L.; Dai, H.; Jin, Z.; Shen, H.; Guan, F.; Yang, Y.; Tabashnik, B.E.; Wu, Y. Evaluating Cross-Resistance to Cry and Vip Toxins in Four Strains of Helicoverpa armigera With Different Genetic Mechanisms of Resistance to Bt Toxin Cry1Ac. Front. Microbiol. 2021, 12, 939, https://doi.org/10.3389/fmicb.2021.670402.

50. Chakrabarty, S.; Jin, M.; Wu, C.; Chakraborty, P.; Xiao, Y. Bacillus thuringiensis vegetative insecticidal protein family Vip3A and mode of action against pest Lepidoptera. Pest Manage. Sci. 2020, 76, 1612-1617, https://doi.org/10.1002/ps.5804. 